\title{
Poema em prosa: da metonímia ao fragmento
}

\author{
Fernando Paixão
}

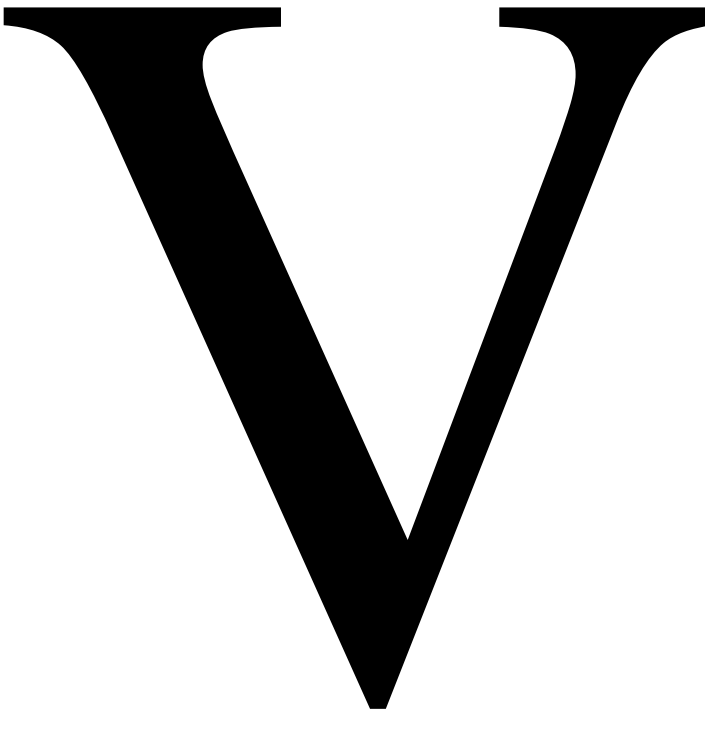

EM DO PENSADOR ITALIANO Giorgio Agamben uma contribuição arguta e interessante para compreender a sutil diferença que há entre os gêneros literários predominantes: poesia e prosa. No título de um de seus livros - sugestivamente chamado Ideia da Prosa -, ele afirma que "nenhuma definição do verso é perfeitamente satisfatória, exceto aquela que assegura sua identidade em relação à prosa através da possibilidade do enjambement"1 (Agamben, 1999, p. 30).

Pressupondo que vivemos numa época em que os discursos e os gêneros embaralham-se e confundem-se, praticamente sem fronteiras entre si, permaneceria ainda essa diferença sutil e mínima - mas de alto impacto na forma - como resguardo da originalidade específica do universo poético. Faz parte da natureza poética, em essência, a valorização da palavra no contexto de cada verso, unidade essa que é coparticipante de um conjunto maior, o poema.

Nessa linha de raciocínio, a poesia como gênero procura justamente tirar proveito estético dessa singularidade. Equivale a dizer que o enjambement cumpre papel fundamental na expressão poética 
devido à sua fina capacidade de interferir no ritmo e até mesmo no imaginário dos versos, sobrepostos uns aos outros. Como consequência, também há interferência no horizonte dos significados ${ }^{2}$.

Corte do pensamento, o enjambement contribui para uma tensão contínua entre som e imaginário, produzindo um efeito mental. Segundo Agamben, "esta suspensão, esta sublime hesitação entre o sentido e o som, é a herança poética que o pensamento deve levar até o fim". Trata-se, como se vê, de ótica que contempla uma perspectiva contemporânea do problema.

Sua abordagem tem a ousadia de considerar o enjambement um elemento menos associado à função rítmica, como costuma ser a tendência natural da crítica estilística. Em um texto curto e sucinto, ele em verdade assume o risco de enfatizar um novo modo de compreender esse artifício tão corriqueiro dos versos.

Tzvetan Todorov (apud Ducrot, 1977, pp. 183-8) também tratara do assunto algumas décadas antes, e chama a atenção para o fato de que "o enjambe$m e n t$ não poderia existir se todas as pausas fossem da mesma natureza". De fato, essa obviedade escapa à primeira vista. Ele sugere, então, que a hesitação entre som e sentido provocada pelo enjambement estaria relacionada igualmente ao fato de os versos serem irregulares e inesperados, obtendo por consequência um efeito correspondente no imaginário.

Conclui-se, portanto, que a prosa e o poema em prosa, por extensão, estariam privados desse efeito de suspensão, pois não apresentam cortes nas frases. Desprovidos da unidade do verso, são gêneros condicionados a outra respiração, outra cadência a conformar o fluxo do texto. Esse fato suscita o desdobramento inevitável e que diz respeito às diferenças existentes entre o poema em prosa e o poema em versos. Afinal, ainda que nutridos pela

1 Enjambement: termo da poética que designa a passagem para o verso seguinte de uma ou várias palavras que completam o sentido do verso precedente; descontinuidade entre a quebra do verso e a unidade sintática.

2 A visão de Agamben torna-se ainda mais ousada ao argumentar que "o enjambement exibe uma não coincidência e uma desconexão entre o elemento métrico e o elemento sintático, como se, contrariamente a um preceito muito generalizado, que vê nela o lugar de um encontro, de uma perfeita consonância entre som e sentido, a poesia vivesse, pelo contrário, apenas da sua íntima discórdia" (Agamben, 1999, p. 32). mesma fonte poética, configuram duas maneiras distintas de composição literária.

E quais seriam essas diferenças? Ao tratar do assunto, Dominique Combe salienta que o poema em prosa contrasta com o texto em versos, sobretudo por seu caráter discursivo. Em sua opinião, "lá onde o poema sugere, a prosa desenvolve, sublinha, por uma sorte de expansão retórica" (Combe, 1989, p. 96). Segundo ela, o poema em prosa parece tipograficamente "mais longo e mais denso" (Combe, 1989, p. 96). Com base na análise de poemas de Baudelaire e de Reverdy, em diferentes versões, Dominique sustenta a tese de que a linearidade tipográfica e a disposição em linhas regulares reforçam a discursividade do poema em prosa: "Em favor da prosa, o poema se narrativiza" (Combe, 1989, p. 97), afirma.

Sua argumentação, no entanto, traz pouca novidade ao diagnóstico feito uma década antes pela crítica literária norte-americana Barbara Johnson (1979), no livro Défiguration du Langage Poétique: la Seconde Révolution Baudelairienne. Nele, a pesquisadora desenvolve um arguto raciocínio que ressalta a segunda revolução desencadeada pelo poeta francês. Ao interpretar dois textos de Baudelaire dedicados ao tema da cabeleira - "Le Chevelure", em versos, e "Un Hemisfère dans une Chevelure", em prosa -, a autora compara as imagens de ambos e aponta a visão conflitiva entre os discursos. Segundo ela:

"[...] enquanto a retórica da peça em versos tende a apagar a diferença entre o sujeito e o objeto por meio de um jogo de correspondências metafóricas, o poema em prosa tende a eliminar essas correspondências suprimindo as personificações que as transmitem" (Johnson, 1979, p. 49).

A autora conclui que o poema em prosa estudado por ela configura um imaginário distinto, substituindo, por exemplo, "as relações de correspondência pelas de diferença", ou ainda "as substituições pelas justaposições, as fusões pelas separações" (Johnson, 1979, p. 50). Tudo

FERNANDO PAIXÃO é professor de Literatura no Instituto de Estudos Brasileiros da Universidade de São Paulo e autor de, entre outros, Palavra e Rosto (Ateliê). 
isso para sustentar sua tese principal em torno da chamada segunda revolução baudelairiana, intensificada posteriormente pela arte de Mallarmé.

Barbara Johnson defende a ideia de que o poema em prosa se caracteriza pela predominância da metonímia como figura de linguagem - em contraposição ao poema em versos, inclinado ao maior emprego de metáforas. Mais que isso: ela considera que a poesia moderna alimenta-se mesmo desse jogo intrínseco provocado pelas diferenças que os discursos afirmam entre si.

De acordo com Barbara, uma das propriedades do poema em prosa seria justamente a de manifestar um desejo de diferença no interior da própria língua. Diferença que começa no plano do léxico geral, na sintaxe e, claro, também nos traços da imaginação. Oxímoro, em essência, o gênero novo não cessa de revelar uma contraposição contínua.

Essa teoria traz à discussão uma perspectiva inovadora, chave para a compreensão ampla dos recursos desse tipo de escrita. É bem verdade que Jean Cohen (1977, p. 52) já havia dito que "verso e metáfora são estruturas homólogas". Essa se tornou então uma ideia consensual, facilitando a leitura e a compreensão de muitas poéticas exploradoras das mil e uma possibilidades do campo metafórico.

Aceita essa premissa, a decorrência natural será a de considerar o poema em prosa, por contraste, mais naturalmente próximo ao campo da metonímia ${ }^{3}$. Barbara Johnson chega a sugerir que o mecanismo dessa figura de linguagem constituiria um elemento estrutural do gênero. Sabendo-se formalmente próximo da prosa, o poema tem a inclinação de resgatar a linguagem ordinária, em oposição à linguagem "poética" dos versos.

Sem dúvida, apoiada num raciocínio ousado e inteligente, o veredicto da autora norte-americana revela-se polêmico e ao mesmo tempo instigante. Tem o mérito, sobretudo, de chamar a atenção para um aspecto tão importante no entendimento da identidade do poema em prosa. Além disso, consegue formular uma ideia-síntese que leva a entender certos mecanismos imaginários ligados ao gênero.

3 Existe uma farta discussão envolvendo os papéis distintos que a metáfora e a metonímia podem desempenhar no discurso poético. A esse respeito, sugerimos a leitura de Preminger e Brogan (1993, p. 783).
Por isso mesmo, ocorre-nos colocar à prova a tese da autora. Não com o objetivo de polemizar com suas ideias, mas sim de avançar no entendimento do tema. Por se tratar de conceitos demasiado abstratos, é sempre útil e esclarecedor recorrer à leitura de algum exemplo.

Vamos encontrá-lo em um texto de Charles Simic, escritor dotado de alta sensibilidade para a escrita de poemas em prosa. Nascido em 1938 na antiga Iugoslávia e radicado nos Estados Unidos, é autor do seguinte poema:

\section{“O Mágico Estudo da Felicidade}

No menor teatro do mundo falam as migalhas de pão. Elas compõem um auto sobre o tema do paraíso perdido. Era uma vez uma cozinha em cuja mesa restavam algumas migalhas. Através da janela era possível ver sua jovem mãe conversando com o vizinho perto da cerca. Ela estava com frio e ficava apertando os braços em torno a seu leve vestido. Enquanto as nuvens velejavam no céu ela levantava a cabeça para rir.

Quando as palavras não podem mais ir adiante resta a mesa sólida. As migalhas estão olhando para você enquanto você as observa de volta. $\mathrm{O}$ desconhecido em você e o desconhecido nelas se atraem uns aos outros. Os dois desconhecidos são como amantes ilícitos quando estão exagerada e inexplicavelmente felizes" (Simic, 1992, in Lehman, 2003, p. 126).

Ao ler devagar a tonalidade confessional e uniforme que essas imagens evocam, a imaginação é despertada. De modo singular, o poema consegue entrelaçar o banal cotidiano com o sentido maior de felicidade, palavra dotada de significativa transcendência. $E$ isso em tão poucas linhas, sugeridas a partir de um momento raro, capaz de despertar um olhar sensível.

A metamorfose da realidade sucede desde a primeira frase, quando as migalhas de pão são associadas a um pequeno teatro, digno de atenção. Desde aí, fica estabelecido um elo entre os planos do abstrato e do real - "no menor teatro do mundo falam as migalhas de pão" -, capaz de inspirar-se nas pequenas coisas para o reconhecimento do entusiasmo.

Ao registrar os momentos em que transcorre a situação, o sujeito poético articula imagens 
relacionadas ao mundo objetivo, mas que, na frase seguinte, remetem a um estado de espírito próximo ao sagrado: "Elas compõem um auto sobre o tema do paraíso perdido". Ora, num poema que se inicia dessa maneira, seria natural esperar uma continuação das frases em estilo elevado, ampliando o nível de abstração.

Mas não é o que sucede. Logo em seguida, o poema muda de tom e de plano, deixando mesmo a impressão de que se reinicia: "Era uma vez uma cozinha em cuja mesa restavam algumas migalhas". Fica assim instaurado o espaço em que serão revelados os personagens e as nuances. A atmosfera geral está anunciada a partir do título, bem se sabe, mas só aos poucos percebemos a qualidade do encontro com a felicidade que sucede naquele ambiente matinal.

Flagrada ao acaso, a cena da mãe que conversa com o vizinho ganha relevância e mistura-se com o céu e as risadas. Mas não é possível capturar em palavras aquele instante fugaz: "Quando as palavras não podem mais ir adiante - resta a mesa sólida". E o reencontro com o pequeno teatro das migalhas certamente se contamina da atmosfera geral e ganha uma qualidade inesperada: "O desconhecido em você e o desconhecido nelas se atraem uns aos outros".

Reconhecido o vínculo imediato e vital, o observador e as migalhas podem ser comparados a amantes ilícitos, tomados de felicidade. A identidade fortuita do momento expressa, então, um sentimento sem possibilidade de expressão. Daí o fato de ser um flagrante precário, espécie de estudo fixado já no pórtico do título: algo a aprender com os restos de pão, algo a compreender com os gestos da jovem mãe.

Não será exagero, portanto, tomar esse poema como um exemplo da predominância da metonímia como elemento organizador das imagens poéticas. Acontece nesse caso o que alguns críticos consideram ser um traço típico da figura de linguagem em questão. De acordo com essa ótica, a natureza metonímica caracteriza-se sobretudo por configurar certo deslocamento de ordem semântica, que possibilita ampliar o significado das palavras ${ }^{4}$.

Aplicada essa ideia ao poema de Simic, é como se ocorresse uma espécie de transferência da subjetividade para o plano das coisas em volta. As migalhas, a cozinha, a janela, a mãe lá fora, a vizinha, as nuvens - percebidas com interesse e identificação - tornam-se assim capazes de resgatar uma fresta de paraíso perdido, redescoberto em escala cotidiana.

Subsiste, portanto, o princípio da metonímia como elemento organizador das imagens e com o poder de promover uma sutil transferência simbólica. Tomando o concreto pelo abstrato, em estreita correspondência de valores, até mesmo a chamada felicidade pode estar sugerida no acaso sensível que a realidade proporciona.

Curioso, então, será fazer uma experiência de leitura do mesmo texto de Charles Simic, mas dessa vez a partir de uma hipotética divisão em versos, algo que certamente deve interferir no ritmo e nos sentidos. Até que ponto uma cirurgia dessa natureza altera a apresentação do imaginário poético? Até por curiosidade, a questão aciona um interessante problema poético.

Tomaremos, então, a liberdade de desdobrar o poema em unidades menores, com o objetivo de ressaltar as ressonâncias naturais da versificação5. Obviamente, tal procedimento implica uma heresia em relação ao original, rompendo com a opção criativa do autor; mas espera-se que o pecado confesso seja perdoável em nome dos aspectos que se quer enfatizar.

De modo arbitrário, o mesmo poema pode ser assim versificado:

"No menor teatro do mundo falam as migalhas de pão.

Elas compõem um auto

sobre o tema do paraíso perdido.

Era uma vez uma cozinha em cuja mesa restavam algumas migalhas.

Através da janela

você podia ver sua jovem mãe conversando com o vizinho perto da cerca.

Ela estava com frio e ficava apertando os braços em torno a seu leve vestido.

4 Raciocínio desenvolvido por Albert Henry (1971 apud Preminger \& Brogan, 1993, p. 784).

5 Segundo Giorgio Agamben (1999, p. 33), a versificação implica uma dubiedade evidente: "A versura que, embora não referenciada nos tratados de métrica, constitui o cerne do verso (e cuja manifestação se vê no enjambement) é um gesto ambíguo que se orienta ao mesmo tempo para duas direções opostas, para trás (verso) e para diante (prosa)". 
Enquanto as nuvens velejavam no céu

ela levantava a cabeça para rir.

Quando as palavras não podem mais ir adiante resta a mesa sólida.

As migalhas estão olhando para você enquanto você as observa de volta.

O desconhecido em você e o desconhecido nelas se atraem uns aos outros.

O dois desconhecidos são como amantes ilícitos quando estão exagerada e inexplicavelmente felizes" (Lehman, 2003, p. 126).

Embora as palavras sejam as mesmas, é possível notar uma leve alteração de ritmo no interior das frases, produzindo algum impacto na apreensão final do texto. Ao se desdobrarem em versos, percebe-se que as frases se desmembram e potencializam cada um dos versos/fragmentos, em contraponto com as outras linhas.

Trata-se, claro, de uma questão de ênfase e não propriamente de fundo. No entanto, é possível perceber certa mudança de tonalidade e de colorido no poema quando as imagens aparecem transfiguradas em versos. É bem verdade que, ao assumir nova feição, o texto perde algo em termos de fluência - e tônus narrativo -, mas ganha outro tanto em riqueza simbólica, acentuando novos significados.

$\mathrm{Na}$ versão versificada, optou-se por interferir o mínimo no texto, fazendo coincidir a cisão dos versos com a pausa semântica. Torna-se evidente que o corte da frase ressalta a singularidade de cada fragmento, mais do que ocorre na fluência original. Aumenta, portanto, o intervalo entre as imagens, e isso também acaba ampliando a porção de ambiguidade, abrindo espaço para novos elos associativos.

Isso fica ainda mais evidente se formos além com a heresia para impor ao movimento do texto ainda outras dobras, recortando os versos na contramão da sintaxe e se entregando ao cavalgamento do enjambement. Submetidas a um corte mais brutal e entrecortado, as imagens poéticas adquirem novas sutilezas.

"No menor teatro do mundo falam

as migalhas de pão. Elas

compõem um auto

sobre o tema do paraíso

perdido.

[...]"
Ou ainda:

"No menor teatro

do mundo falam as migalhas

de pão. Elas compõem um auto

sobre o tema do paraíso

perdido.

[...]"

$\mathrm{Ou}:$

"No menor teatro

do mundo

falam as migalhas

de pão.

Elas compõem

um auto

sobre o tema do paraíso

perdido.

[...]".

Torna-se fácil perceber como, à medida que o enjambement se torna mais recorrente entre os versos, aumenta o grau de amplitude das palavras. A operação é sutil, pois não altera o núcleo da frase, mas revela nuances quando entregues a outras variantes, outros recortes - configurando síncopes diferentes do ritmo do original.

Quanto mais recortada e inusitada for a transposição em versos, maior será o desmembramento da imagem, gerando influência na carga poética de cada palavra ou de cada linha. Aumenta também a complexidade do ritmo dos versos à medida que se tornam mais curtos e sobrepostos. Percebe-se visualmente a desintegração da unidade original - em nome de atenções recortadas, versos com sentido próprio, fragmentação. Torna-se evidente que o texto experimental se afasta da naturalidade encontrada na frase do poema original, em prosa.

Mais ainda: parece-nos que o simples desmembramento das frases rompe com o caráter de contiguidade do poema em prosa, resultando na atenuação do seu veio metonímico. Submetido à versificação, o texto de Charles Simic apresenta notória torção de sentidos a fim de expressar as imagens poéticas de modo menos linear, mais próximas do campo metafórico. Em resumo, a fragmentação expande as associações evocadas no interior dos versos. Quanto mais a sintaxe se apresenta 
fragmentada, mais se multimplicam os sentidos.

Uma conclusão dessa ordem vai ao encontro das ideias de Barbara Jonhson, em sua defesa de que o poema em prosa identifica-se com a metonímia, em contraposição à tendência metafórica dos versos. Viu-se isso acontecer com o poema de Charles Simic, anteriormente. E parece mesmo ser essa a inclinação natural do poema em prosa, a ponto muitas vezes de se tornar um fator determinante para a escolha dos recursos estilísticos.

Contudo, não se deve tomar tal premissa como genérica, válida para todos os textos, sob o risco de engessar uma expressão tão rica e variada. Antes, cada poema deve ser lido à luz de seus próprios elementos, como peça única, sem a influência de considerações prévias. Até porque faz parte do espírito da modernidade literária justamente a tradição de negar e romper com os modelos preexistentes, sem permitir a estabilidade de modelos fixos.

Para evitar o âmbito do postulado, é pertinente considerar o poema em prosa um tipo de escrita em que o imaginário, com frequência, recorre ao signo da metonímia. Definição que sinaliza uma tendência - o que não é pouco. Por conta da discursividade que governa o fluxo das frases, ou da referencialidade que costuma apresentar em seus textos, resulta predominante muitas vezes o princípio organizador da contiguidade, tão característico dessa figura de linguagem.

Quem faz considerações semelhantes no campo da poética em geral é o pensador russo Roman Jakobson que, em seus escritos linguísticos, associa a imaginação da poesia com a metáfora, enquanto a metonímia estaria presente na "chamada literatura realista”. Jakobson (1974, p. 156; 1987) afirma ser típico desse tipo de prosa apresentar certa "textura metonímica", caracterizada por palavras que sofrem deslocamento de sentido, mas não se afastam do conteúdo literal que carregam.

Com essa argumentação, não deseja decretar a polaridade fixa entre os gêneros; está mais interessado em decifrar a diferente representação implicada nas duas figuras de linguagem. Jakobson entende que a metáfora é uma figura usualmente associada a um emissor, interessado em expressar de modo original os sentimentos e as emoções; a natureza do seu emprego estaria vinculada ao caráter solipsista de certa expressão poética.
Em contrapartida, a via da metonímia permite ao sujeito lírico deslocar-se para uma realidade outra que a das emoções. Ao promover os deslocamentos de sentido, típicos dessa imaginação, inscreve de modo indireto uma visão particularizada da realidade. Daí o mundo exterior ser tomado como ponto de partida, estímulo às imagens e aos deslocamentos, mas para delinearem uma percepção que escapa ao normal e toma ares de surpresa.

Voltando ao poema de Simic, presenciamos efeito semelhante na cena das migalhas de pão distraídas sobre a mesa. Logo na segunda frase, são associadas a um "auto sobre o tema do paraíso perdido". Sem justificativa, o poeta salta da circunstância para o reino do "Era uma vez...".

$$
* * *
$$

Aceita a premissa de que a metonímia está presente no DNA desse tipo de escrita, o tópico ainda não se encerra por completo. Ressalta um aspecto importante, predominante até, mas que costuma ser entendido no âmbito formal, sem se estender ao imaginário evocado por esse tipo de linguagem assunto que nos interessa.

Especificamente, cabe entender as implicações poéticas da retórica metonímica no campo do poema em prosa, e que marcas de estilo podem engendrar no plano das imagens e do ritmo. A bibliografia sobre esse item específico é inexistente; no entanto, trata-se de um bom problema e que permite avançar na reflexão.

Para tanto, voltamos a recorrer a um exemplo que possibilita a análise e o aclaramento das ideias. É o caso de um texto do poeta espanhol contemporâneo Andrés Sánchez Robayna, que tem a qualidade de explicitar desde a primeira frase o jogo metonímico em torno do qual se desenvolve.

\section{"SistemA}

O fio da tarde descansa sobre a folha roxa. Veja o outono. Veja. Sobre a folha veja o outono. A folha roxa em que descansa o outono, veja-a. O fio da tarde descansa. Veja-o roxo.

Diria que a folha roxa descansa sobre uma hora indecisa. A hora indecisa como o leito em que a folha descansa. Digo: dir-se-ia que a folha roxa descansa sobre uma hora indecisa; escrevo-o e leio-o. E o desleio: prevejo que a folha e a hora podem se associar de outra forma, establecer uma corrente; 
veja a hora como uma folha, em seu descanso de outono" (Robayna, 2003).

O poema apresenta em torno à folha roxa uma espiral de significados, mas todos contemplados pelo princípio da substituição, essencial à metonímia ${ }^{6}$. A mera folha não se resume a ser o que é, para logo produzir um halo de representação em torno àquela especial tarde de outono. Não se trata, porém, de uma substituição simbólica estável. De modo incisivo, o leitor recebe a ordem: veja. Mas a folha (sempre roxa) logo muda em seguida; indecisão que faz girar o poema.

Até quando a primeira pessoa irrompe entre as frases e assume o artifício: "escrevo-o e leio-o". Era a voz que pesava sobre o verbo no imperativo, usado antes: "Veja... Veja... Veja". Por conseguinte, a folha não somente diz respeito ao ar da tarde, mas também ao olhar de quem produz a dicção, articula o encontro das palavras; até que, ao fim, as frases superam a indecisão e alcançam a harmonia: "a hora como uma folha, em seu descanso de outono".

De modo acumulativo, a construção do poema sugere mesmo a elaboração interna de uma metonímia. Algo a ser tomado por outro, em substituição sinal de um sistema. O objeto deixa de existir por si para fazer conexão com o entorno, impregnado de uma visão humana quanto ao tempo e ao espaço. Por fim, percebe-se que toda a dramaticidade expressa pela folha diz respeito ao sujeito lírico.

Em algum nível, todo texto poético responde a uma ótica subjetiva, mesmo quando não ocorre referência à primeira pessoa. Constitui recorte de uma visão de mundo que organiza os elementos evocados e captura elos significativos em associação livre. Por isso, importa menos o ponto de partida do poema e mais o caminho que percorre nas imagens e relações subsequentes, abrindo espaço para um sentido que se amplia.

Ainda que a folha seja um elemento distraído do mundo, ela pode carregar em si todo o peso da tarde: fragmento que atrai imagens de outra dimensão. Fragmento, enfim, que acena para além de si, estabelece relações e desperta palavras que

6 Em síntese, a metonímia pode ser definida como figura de linguagem em que uma palavra é substituída por outra com base em algum aspecto que seja material, causal ou de relação conceitual (Preminger \& Brogan, 1993, pp. 783-5). não estavam previstas no mapa do cotidiano. Ao mesmo tempo em que participa do todo, consegue ganhar individualidade, cria uma fenda na tarde.

Assim, se quisermos definir de modo mais amplo: o fragmento configura certa relação com a totalidade. Como aconteceu naquele dia outonal e, com frequência, sucede nos poemas em prosa de inspiração metonímica. Para que a folha incorporasse as qualidades da tarde, foi necessário atravessar a hora intranquila, ponto de tensão entre as duas dimensões. O poema de Sánchez Robayna dramatiza justamente o processo de superação da condição inicial da folha, inerte, para um descanso final e integrado ao ambiente. A seu modo, o texto opera uma transmutação simbólica.

A relação entre particular e universal, contudo, pode assumir diversas modulações e sentidos; tantos quantos forem os entendimentos da palavra fragmento. Conceito-chave que é, remonta à longínqua tradição literária dos românticos alemães e perpassa uma larga corrente de autores. A própria modernidade pode ser associada ao reconhecimento de que o absoluto se tornou impossível e que resta ao homem a percepção do todo somente pelo prisma de seu mundo fragmentado, conforme o postulado de Victor Hugo em seu estudo sobre o grotesco e o sublime?

Friedrich Schlegel foi outro pioneiro do Oitocentos a tocar no assunto em suas reflexões. Diz ele: "um fragmento tem de ser como uma obra de arte, totalmentte separado do mundo circundante e perfeito e acabado em si mesmo como um porco-espinho" (Schlegel, 1997, p. 82). Comparação esdrúxula, numa primeira impressão, mas certeira porque afinada com uma visão de mundo idealizada e voltada para o plano subjetivo, de pelos eriçados contra o meio social.

Não é o caso de fazer aqui um recenseamento histórico ou crítico sobre o tema, mas sim associar o conceito de fragmento à noção de poema em prosa - o primeiro entendido como fator constitutivo e determinante para a linguagem do segundo ${ }^{8}$. Nesse sentido, ninguém melhor do que Roland Bar-

\footnotetext{
7 Ideia defendida pelo autor em seu famoso

"Prefácio a Cromwell", traduzido em Hugo (2007). Ver também Friedrich (1978, p. 33).

8 Pedro Aullón de Haro (2005, p. 22) chega a afirmar que o poema em prosa, "junto com o ensaio e o fragmento, constitui a única entidade de gênero literário novo e de valor geral produzido nos tempos modernos".
} 
thes para subsidiar a questão. Escritor de método confessadamente fragmentário, ele contrapunha a liberdade de escrita e de pensamento com um organizadíssimo sistema de fichas e anotações, que serviam de fonte para seus ensaios. Barthes pode mesmo ser considerado um crítico que elevou o fragmento ao estatuto de gênero.

No livro de 1975, em que se autoapresenta, ele registra algumas notas instigantes sobre $\mathrm{o}$ assunto. Segundo ele, na ótica budista o fragmento "implica um gozo imediato: é um fantasma de discurso, uma abertura de desejo". Em sua concepção ideal, deve transmitir "alta condensação, não de pensamento, ou de sabedoria, ou de verdade (como na máxima), mas de música; ao 'desenvolvimento', opor-se-ia o 'tom', algo de articulado e de cantado, uma dicção". Por fim, Barthes (1977, pp. 102-3) define esse tipo de escrita como um "gênero retórico".

Ora, essas palavras servem muito bem para dar um passo adiante na compreensão da dinâmica poética do poema em prosa e de suas potencialidades intrínsecas. Inclusive a de contar com o pendão da retórica metonímica para alinhavar as imagens, que igualmente procuram despertar gozos imediatos, fantasmas de discurso, janelas de desejos... Por outro lado, deve ser levado em conta o fato de que essa mesma linguagem também salienta a aptidão fragmentária que norteia esse tipo de escrita ${ }^{10}$. Nas relações entre forma e conteúdo, via de mão dupla, não se sabe o que vem antes.

Como se dá a ver no texto de Robayna, cujo tema se apresenta em frases curtas, secas e num ritmo por vezes dissonante, o plano formal expressa de maneira orgânica a inquietação da hora. Essa inquietação expressa ainda a dimensão inacabada do mundo, tensa, em constante mutação. E que o poema registra num instantâneo. Inquietação, inacabamento, intensidade... sensações de instabilidade que perfazem uma experiência momentânea e interior.

Parece que a natureza do poema em prosa (de modo geral, não apenas nesse exemplo) implica mesmo a condição fragmentária - eis o ponto a destacar. E que suscita amplas consequências no

9 Sobre a escrita fragmentária, ver também Blanchot (1987). Ou, do mesmo autor, o ensaio "Nietzsche e a Escritura Fragmentária", que pode ser lido em Blanchot (1973, pp. 41-66).

10 Ao referir-se a si mesmo, Barthes (1977, p. 102) afirma: "eis por que ele escreve fragmentos: tantos fragmentos, tantos começos, tantos prazeres...". desempenho da linguagem. A começar, pela associação corriqueira que se faz entre a noção de fragmento e a ideia de falha, fracasso ou, até mesmo, de uma verdadeira patologia do ser (Susini-Anastopoulos, 1977, p. 60). Não por acaso, muitas vezes assume o caráter de anotação íntima e reflexiva.

Isso quer dizer que a escrita assim concebida abre mão de ser plena para entremostrar-se parcial e frágil; na contramão dessa fraqueza, porém, o poema procura afirmar a singularidade de seu imaginário e da solução formal. A condição fragmentária, pois, transforma-se em elemento motivador, ponto de partida para a imaginação.

Vamos agora recorrer a outro exemplo para reforçar essa questão. E, nesse caso, não é nada difícil encontrar opções. Fiquemos então com um texto do poeta francês René Char, inspirado no ângulo da memória.

\section{“Declarar seu Nome}

Eu tinha dez anos. O Sorgue era meu altar. O sol cantava as horas no quadrante sereno das águas. A indiferença e a dor grudaram o galo de ferro no telhado das casas e se aturavam juntas. Mas que roda no coração da criança à espreita girava mais forte, mais ágil, que a do moinho em seu branco incêndio?" (Char, 1995, p. 57).

A evocação de um tempo e de um lugar de outrora, entrecruzados em uma situação específica, costuma ser um recurso habitual nesse tipo de composição. No poema de Char, o eu coloca-se afirmativo desde a primeira frase e engata o solipsismo que enfeixa os ditos seguintes. Submetidas à brevidade, as imagens selecionadas entrecortam a realidade em flagrantes, de modo a ressaltar aspectos que resumem o clima geral: o altar, o sol, a indiferença e a dor estabelecem um vínculo forte de circunstância.

Mas o poema se desestabiliza ao final, arrematando uma longa pergunta em torno da miragem do moinho, confundido com um "branco incêndio". Em seguida, o idílio do passado de repente se vê substituído pelo presente da dúvida - e o poema se reparte em dois tempos. No conjunto, temos uma espécie de collage de imagens, reunidas, em tom confessional, sob o signo da intimidade do eu dividido. A fragmentação dos sentidos e a das 
coisas - e mesmo a curvilínea dúvida derradeira - disparam equivalentes verbais em ritmo único.

É interessante notar a contraposição entre o possessivo de terceira pessoa do título e o uso da primeira pessoa logo no início do poema. Esse contraste sugere certo vínculo entre o sujeito lírico (figurado na percepção dos sentidos) e a universalidade da experiência de encantamento, própria da infância. Com a marca da intensidade, o poema recupera certa idade, lugar, dia e hora, superados (ou não?) pela forte alvura do moinho. Contrariando a harmonia da lembrança, as informações externas das primeiras quatro frases se desmontam com a mudança de tom e inquietação da última.

Esse texto, bem como o de Charles Simic e o de Sánches Robayna, pode ser compreendido na perspectiva que alguns críticos atuais chamam de estética do fragmentarismo. Por se contrapor ao mero fragmento (dependente de outras partes para recompor o todo), o conceito de fragmentarismo se caracterizaria por um tipo de discurso espontâneo, em que a motivação central não é mais "a remissão a um passado explicador, se não a mesma ausência de centro, uma linguagem que encontra na autoimolação seu princípio de linguagem" (Talens, pp. 78-9) ${ }^{11}$.

Equivale a dizer que é por meio da ambiguidade e do inacabamento que a condição fragmentária expressa seu vínculo com a totalidade. Não é outra, portanto, a vocação do poema em prosa; sobretudo depois do experimentalismo que se alastrou no século XX e intensificou o gosto pela vertigem das imagens poéticas. Na estética contemporânea, convive-se com a noção distinta de fragmento e distanciada do modelo romântico, preso em demasia a um paroxismo sem saída: desejar o absoluto, mas resignar-se à impossibilidade e à finitude precária do mundo. A poética oitocentista em muito se alimentou desse imaginário.

Em contrapartida, o fragmentarismo contemporâneo apresenta uma performance que promove o desvio dessa condição autocentrada. Convivemos com a noção de fragmento que "não é mais o porco-espinho ou o cartouche que reflete e supera a si mesmo em direção ao infinito, mas é o méros

11 Sobre o assunto, ver também as conclusões de Fernández (1996, pp. 129-31). grego, isto é, a parte, o destino que diz respeito a cada um", conforme dizeres do crítico italiano Mario Perniola. Ao caracterizar a estética de nossos dias e relacioná-la ao conceito de fragmento, ele resgata um conceito da Antiguidade que relaciona as ideias de parte e destino, significados que os gregos denominavam por uma só palavra: moîra, o mesmo que porção (Perniola, 2010, p. 149).

$\mathrm{O}$ fragmentarismo incorporado à nossa sensibilidade refaz a cada porção - ou situação poética - a pergunta por um destino. Como ocorreu com as migalhas de pão sobre a mesa, a folha caída na rua ou o refúgio dos dez anos - cada cena desperta um círculo de indagações sobre as coisas e a percepção dos sentidos. À sua maneira, cada texto articula certa tensão entre situação e destino, singularidade despertada por qualquer estímulo do cotidiano.

São poemas que expressam um imaginário afinado com a noção contemporânea de fragmento: "o que conta não é a pretensão de ser tudo, mas exatamente ao contrário; promover a descoberta das infinitas ligações, conexões, interdependências que nos enraízam no mundo" (Perniola, 2010, p. 150). Antes de desejar alcançar o absoluto, o poeta de nossos dias dá voz a uma visão cindida entre a sondagem de totalidade e a atenção às coisas miúdas e particulares (Perniola, 2010, pp. 139-50). $O$ próprio dilema entre as duas esferas se transforma em tensão expressiva, a tal ponto que Perniola a denomina com uma expressão sugestiva: "paradoxo do fragmento".

Tal característica encontra-se no gênero desde a origem - a exemplo do que se lê nos textos de Baudelaire -, mas intensificou-se e tornou-se predominante com a experimentação e o alargamento da imaginação poética ocorrido no século seguinte. De certo modo, pode-se afirmar que o gênero apresenta uma trajetória que tem início com o fragmento romântico e chega ao fragmentarismo contemporâneo, sendo o segundo a exacerbação do primeiro.

Por certo, o fragmentarismo não se restringe ao poema em prosa; mas, efetivamente, contribui para o entendimento de sua dinâmica como escrita peculiar. Ademais, está em sintonia com o uso da metonímia e suas peculiaridades de linguagem. Por conta da atenção poética miúda e fragmentária, os detalhes conseguem flagrar uma totalidade que transcende ao mero cotidiano. $\mathrm{O}$ fragmento como aceno de totalidade precária. 


\section{BIBLIOGRAFIA}

AGAMBEN, Giorgio. Ideia da Prosa. Lisboa, Cotovia, 1999.

BARTHES, Roland. Roland Barthes por Roland Barthes. São Paulo, Cultrix, 1977.

BLANCHOT, Maurice. La Ausencia del Libro/Nietzcshe y la Escritura Fragmentaria. Buenos

Aires, Ediciones Caldén, 1973. . L'Écriture du Desastre. Paris, Gallimard, 1987.

CHAR, René. O Nu Perdido e Outros Poemas. Tradução de Antonio Contador Borges. São Paulo, lluminuras, 1995.

COHEN, Jean. Structure du Langage Poétique. Paris, Flammarion, 1977.

COMBE, Dominique. Poésie et Recit: une Rhétorique des Genres. Paris, José Corti, 1989.

DUCROT, Oswald. Dicionário Enciclopédico das Ciências da Linguagem. São Paulo, Cultrix, 1977.

FERNÁNDEZ, José Enrique Martinez. El Fragmentarismo Poético Contemporáneo. León,

Universidad de León, 1996.

FRIEDRICH, Hugo. Estrutura da Lírica Moderna. Tradução de Marise M. Curioini. São Paulo, Duas Cidades, 1978.

HARO, Pedro Aullón de. "Teoría del Poema em Prosa", in Quimera: Revista de Literatura, no 262, 2005.

HENRY, Albert. Métonymie et Métaphore. Paris, Klincksieck, 1971. HUGO, Victor. Do Grotesco e do Sublime. São Paulo, Perspectiva, 2007.

JAKOBSON, Roman. "Linguística e Poética", in Linguística e Comunicação. São Paulo, Cultrix, 1974.

"The Metaphoric and Metonymic Poles", in Language in Literature. Cambridge, Harvard University Press, 1987.

JOHNSON, Barbara. La Défiguration du Langage Poétique: la Seconde Révolution

Baudelairienne. Paris, Flammarion, 1979, pp. 76-82.

LEHMAN, David. Great American Prose Poems: from Poe to the Present. Nova York, Scribner Poetry, 2003.

PERNIOLA, Mario. Desgostos: Novas Tendências Estéticas. Florianópolis, Editora UFSC, 2010. PREMINGER, Alex; BROGAN, T. V. F. (orgs.). The New Princeton Encyclopedia of Poetry and Poetics. Nova Jersey, Princeton University Press, 1993.

ROBAYNA, A. S. "Sistema", in Revista Inimigo Rumor, no 14. São Paulo/Rio de Janeiro, Cosac Naif/7 Letras, 2003, p. 16.

SCHLEGEL, Friedrich. O Dialeto dos Fragmentos. São Paulo, Iluminuras, 1997.

SUSINI-ANASTOPOULOS, Françoise. L'Écriture Fragmentaire: Définitions et Enjeux. Paris,

Presses Universitaires de France, 1977.

TALENS, Jenaro. El Sujeto Vacío: Cultura e Poesía en Território Babel. Madri, Cátedra, 2000. 